\title{
PENGEMBANGAN PERANGKAT PEMBELAJARAN MATEMATIKA UNTUK MENINGKATKAN KEMAMPUAN BERPIKIR KRITIS DAN SELF EFFICACY SISWA DENGAN MENGGUNAKAN MODEL PROBLEM BASED LEARNING DI SMA SULTAN ISKANDAR MUDA T.A 2017/2018
}

\author{
Wilda Indah Yonalia Lubis ${ }^{1}$, Yulita Molliq ${ }^{2}$, Kms.M. Amin Fauzi ${ }^{3}$
}

\begin{abstract}
ABSTRAK
Penelitian ini bertujuan untuk mendeskripsikan: 1) efektivitas perangkat pembelajaran model PBL dalam meningkatkan kemampuan berpikir kritis dan Self Efficacy siswa SMA; 2) peningkatan kemampuan berpikir kritis dan Self Efficacy siswa SMA dengan menggunakan perangkat pembelajaran model PBL; Penelitian ini merupakan penelitian pengembangan. Penelitian ini dilakukan menggunakan model Dick and Carrey. Populasi dalam penelitian ini adalah seluruh siswa SMA kota Medan, pengambilan sampel menggunakan purposive sampling dan sekolah yang dijadikan sebagai subjek untuk uji coba adalah SMA Sultan Iskandar Muda kelas XI- IPA 1. Dari hasil uji coba I dan uji coba II diperoleh: 1) perangkat pembelajaran memenuhi keefektifan, efektivitas ditinjau dari a) ketuntasan belajar siswa secara klasikal; b) ketercapaian tujuan pembelajaran; dan c) waktu pembelajaran; 2) peningkatan kemampuan berpikir kritis dan Self Efficacy siswa dengan menggunakan perangkat pembelajaran model PBL; Selanjutnya, disarankan agar guru dapat menggunakan perangkat pembelajaran model PBL sebagai alternatif pembelajaran, dengan bimbingan atau pertanyaan-pertanyaan yang diberikan dapat terjangkau oleh siswa, sehingga siswa lebih mudah memahami masalahmasalah yang diberikan.
\end{abstract}

\section{Kata Kunci : Model PBL Berpikir Kritis, Self Efficacy, dan model pengembangan Dick and Carey}

\section{PENDAHULUAN}

Pendidikan merupakan suatu bagian yang terpenting dalam kehidupan ini.Kemajuan suatu bangsa dapat dilihat dari kualitas pendidikan pada negara tersebut.Pendidikan merupakan sarana untuk mewujudkan sumberdaya manusia yang memiliki pengetahuan, keterampilan, dan sikap handal dan dapat membantu menyelesaikan segala permasalahan yang ada pada bangsa ini. Tanpa peranan pendidikan maka negara akan mengalami kemunduran dan akan menghasilkan sumber daya manusia yang tidak memiliki pengetahuan, sikap dan keterampilan yang baik.

Menurut NCTM : 2000, tujuan pembelajaran matematika adalah mengembangkan : kemampuan mengeksplorasi, menyusun konjektur, dan menyusun alasan secara logis, kemampuan menyelesaikan masalah non rutin, kemampuan berkomunikasi secara matematis dan menggunakan matematika sebagai alat komunikasi, kemampuan menghubungkan antar ide matematika sebagai alat komunikasi, kemampuan menghubungkan antar ide matematika dan antar matematika dengan aktivitas intelektual lainnyaf. Agar pembelajaran matematika terasa lebih mudah maka

${ }^{1}$ Corresponding Author: Wilda Indah Yonalia Lubis

Program Magister Pendidikan Matematika, Universitas Negeri Medan, Medan, 20221, Indonesia

E-mail: wildalubis37@gmail.com

${ }^{2}$ Co-Author: Yulita Molliq \& Kms.M. Amin Fauzi

Program Studi Pendidikan Matematika, Universitas Negeri Medan, Medan, 20221, Indonesia pengajaran matematika yang bersifat teacher centered dan pemakaian rumus semata harus ditinggalkan agar kemampuan matematika siswa berkembang dengan baik.

Salah satu kemampuan matematis yang perlu dikembangkan adalah kemampuan berpikir kritis. Hal ini dikarenakan dari hasil analisis PISA tahun 2012 yang mengukur kemampuan literasi membaca, matematika dan sains siswa diperoleh skor Indonesia pada kemampuan matematika adalah 375 dari skor rata - rata 494.Dari hasil ini pemerintah sedang menggalakkan kurikulum yang sangat membantu untuk meningkatkan pola pikir siswa. Sesuai dengan Permendikbud No. 21 tahun 2016 tentang standard isi pendidikan dasar dan menengah yaitu "Kompetensi inti yang harus dimiliki siswa untuk semua jenjang pendidikan adalah kemampuan berpikir kritis".

Siswa diharapkan dan dituntut untuk memiliki keterampilan dan kemampuan berpikir kritis matematis agar memiliki kompetensi yang sesuai dengan kompetensi yang akan dicapai dan memiliki kecakapan berpikir. Sejalan dengan pendapat Simbolon dkk (2017) juga mengungkapkan bahwa " keterampilan berpikir kritis diperlukan dalam pembelajaran matematika, karena memiliki peran yang sangat dominan dalam mendidik siswa. Siswa diharapkan mampu mengelola informasi untuk dapat bertahan hidup dalam keadaan yang selalu berubah, tidak pasti dan kompetitif'.

Selain kemampuan berpikir kritis matematis siswa, kepercayaan diri (self efficacy) juga mempengaruhi pengetahuan dan pemahaman siswa tentang

Pengembangan Perangkat Pembelajaran Matematika Untuk Meningkatkan Kemampuan Berpikir Kritis Dan Self Efficacy Siswa Dengan 
matematika. Hal ini sesuai pendapat Harida (2012: 8) mengungkapkan bahwa : "Self Efficacy rendah dapat terjadi karena seseorang belum mengenal potensi dirinya dan hambatan - hambatan dalam pengembangan potensi diri tersebut. Pengembangan diri harus diawali dengan pengenalan diri, salah satu caranya adalah melalui pengukuran potensi diri. Pengenalan diri akan membantu individu melihat kemampuan yang ada pada dirinya, mengetahui hal hal yang berkembang dengan hal - hal yang masih perlu dikembangkan. Seseorang yang cenderung berprestasi rendah pada suatu mata pelajaran dapat menyebabkan seseorang yang cenderung berprestasi rendah pada suatu mata pelajaran dapat menyebabkan orang tersebut tidak percaya diri atau memiliki perasaan tidak mampu dalam menyelesaikan masalah".Self Efficacy merupakan aspek psikologis yang sangat diperlukan siswa untuk dapat menyelesaikan tugas dengan baik. Dalam meningkatkan kemampuan berpikir kritis dan self efficacy siswa maka dalam proses pembelajaran guru merupakan salah satu komponen yang memegang peranan yang sangat penting. Guru bukanlah hanya sebagai penyampai materi namun guru haruslah dapat berperan sebagai desainer pembelajaran.Sehingga diharapkan dapat membuat desain pembelajaran yang menarik efektif sehingga siswa memiliki rasa senang dan respon positif terhadap materi yang telah dipelajari.

Pentingnya pengembangan perangkat pembelajaran bagi seorang guru, dimana perangkat pembelajaran merupakan panduan, artinya perangkat pembelajaran tersebut memberikan arahan kepada guru dalam melaksanakan proses pembelajaran yang telah disusun secara sistematis. Perangkat pembelajaran merupakan tolak ukur, artinya di dalam perangkat pembelajaran pasti memiliki alat evaluasi baik itu tes, non tes, ataupun LKS.

Pengembangan perangkat pembelajaran merupakan peningkatan kualitasdiri, artinya dengan adanya pengembangan perangkat pembelajaran yang telah dilakukan guru, ini memperlihatkan bahwa guru tersebut telah menunjukkan keprofesionalannya sebagai guru. Perangkat pembelajaran itu mempermudah, artinya dengan dikembangkannya suatu perangkat pembelajaran sedemikian rupa akan mempermudah guru dalam proses pembelajarannya tanpa harus berpikir lagi hal apa atau bagaimana materi yang akan diajarkan.Dalam hal ini guru dituntut untuk lebih kreatif untuk mengembangkan perangkat pembelajaran yang menarik dan dapat menumbuhkan keingintahuan siswa terhadap materi tersebut. Surya dan Syahputra (2017) mengungkapkan " bahwa dalam pembelajaran dikelas, siswa tidak terbiasa untuk berpikir deduktif aksiomatik, dan juga siswa tidak didukung oleh buku teks yang akan mereka gunakan". Pengembangan perangkat pembelajaran merupakan tanggung jawab setiap guru, sebisa mungkin perangkat pembelajaran tersebut seefektif mungkin mengaktifkan proses belajar siswa.
Selain mengembangkan perangkat pembelajaran di sekolah, dalam sistem pendidikan sering ditemukan hal yang selalu ingin ditingkatkan yaitu self efficacy dan kemampuan berpikir kritis, hal ini mendapat perhatian khusus, karena siswa yang memiliki kemampuan berpikir kritis, nantinya akan lebih dapat menerima, menyeleksi dan memproses dengan baik informasi yang datang padanya. Hal itu terlihat pada upaya - upaya pengambil kebijakan dibidang pendidikan untuk memasukkan komponen ini dalam kegiatan pendidikan, baik dimuat dalam kurikulum, strategi pembelajaran maupun perangkat pembelajaran lainnya. Upaya tersebut dimaksudkan agar supaya setiap kegiatan pendidikan atau pembelajaran, kepada siswa dapat dilatihkan keterampilan yang dapat mengembangkan kemampuan berpikir kritis dan self efficacy. Dengan demikian dunia pendidikan akan memberikan kontribusi yang besar terhadap pengembangan SDM yang berpikir kritis dan memiliki self efficacy yang handal menjalani masa depan yang penuh tantangan.

Menyikapi permasalahan tersebut diperlukan model pembelajaran yang menganut paham konstruktivisme dimana siswa membangun sendiri kemampuannya adalah dipergunakan model Problem Based Learning. Model ini sesuai untuk meningkatkan kemampuan kemampuan berpikir kritis dan self efficacy siswa. Happy (2014) menyatakan bahwa problem based learning lebih efektif dibandingkan pembelajaran konvensional ditinjau dari (a) kemampuan berpikir kritis matematis, (b) kemampuan berpikir kreatif matematis, dan (c) self esteem. Senada dengan Nurhadi, dkk (dalam Sari : 2013) menyatakan "belajar akan lebih bermakna apabila siswa atau anak didik mengalami sendiri apa yang dipelajarinya".

Model Pengembangan yang digunakan dalam penelitian ini adalah model Dick\& Carrey. Trianto (2010) mengatakan bahwa Dick \& Carrey menunjukkan bahwa telah banyak pengembangan bahan ajar yang mengikuti urutan sejara ajeg dan berhasil mengembangkan bahan ajar yang efektif.

Suparman (2014) menyatakan model pengembangan pembelajaran The systematic Design of Instructional karangan Dick and Carey memiliki setiap langkah yang terhubungkan dengan langkah - langkah merevisi kegiatan pembelajaran. Sehingga sangat cocok bagi perancang pemula sebagai dasar mempelajari model desain. Dalam hal lain menurut Campbell (1999), terdapat beberapa langkah untuk mengetahui keefektivan bahan ajar, dan langkah - langkah tersebut sesuai dengan langkah - langkah yang terdapat dalam model pengembangan Dick \& Carey.

Berdasarkan hal tersebut maka penulis tertarik untuk mengembangkan perangkat pembelajaran menggunakan model pembelajaran PBL untuk meningkatkan kemampuan berpikir kritis dan self efficacy siswa di SMA Sultan Iskandar Muda Medan.

\section{KAJIAN TEORITIS}

Pengembangan Perangkat Pembelajaran Matematika Untuk Meningkatkan Kemampuan Berpikir Kritis Dan Self Efficacy Siswa Dengan 


\section{Perangkat Pembelajaran \\ Perangkat pembelajaran adalah alat atau} perlengkapan untuk melaksanakan proses yang memungkinkan pendidik dan peserta didik melakukan kegiatan pembelajaran. Dalam Permendikbud No. 65 Tahun 2013 tentang standard proses pendidikan dasar dan menengah disebutkan bahwa penyusunan perangkat pembelajaran merupakan bagian dari perencanaan pembelajaran.

Menurut Kemp ( dalam Trianto,2011: 179) pengembangan perangkat merupakan suatu lingkaran yang kontinu. Tiap - tiap langkah pengembangan berhubungan langsung dengan aktivitas revisi. Pengembangan perangkat pembelajaran yang akan dilakukan dalam penelitian ini meliputi : Buku Guru dan Buku Siswa.

\section{Buku Guru}

Buku Guru adalah panduan bagi guru dalam melaksanakan pembelajaran di kelas. Buku Guru memiliki fungsi sebagai : (1) petunjuk penggunaan buku siswa yang harus dipelajari oleh guru terlebih dahulu, (2) acuan kegiatan pembelajaran di kelas, (3) Penjelasan metode dan pendekatan pembelajaran yang digunaka dalam proses pembelajaran.

\section{Buku Siswa}

Buku Siswa adalah buku yang diperuntukkan bagi siswa yang dipergunakan sebagai panduan aktivitas pembelajaran untuk memudahkan siswa dalam menguasai kompetensi tertentu. Buku Siswa bukan sekedar bahan bacaan, tetapi juga digunakan untuk melaksanakan kegiatan - kegiatan dalam proses pembelajaran dimana isinya dirancang dengan contoh - contoh lembar kegiatan dengan tujuan agar dapat terselenggaranya pembelajaran kontekstual.

Beberapa kriteria untuk menentukan kualitas hasil pengembangan perangkat pembelajaran antara lain : validitas, kepraktisan dan keefektifan, karena untuk menghasilkan perangkat pembelajaran yang baik perlu ditempuh suatu prosedur tertentu, yakni dengan mengacu pada model pengembangan perangkat pembelajaran. Nieveen \& Plomp (2007: 26) mengatakan ada 3 kriteria untuk menentukan kualitas model dan perangkat pembelajaran, yaitu :

The components of the intervention should be based on state-of-the- art knowledge (content validity) and all components should be consistently linked to each other (construct validity). If the intervention meets these requirements it is considered to be valid. Another characteristic of high-quality interventions is that end-users (for instance the teachers and learners) consider the intervention to be usable and that it is easy for them to use the materials in a way that is largely compatible with the developers' intentions. If these conditions are met, we call these interventions practical. A third characteristic of high quality interventions is that they result in the desired outcomes, i.e. that the intervention is effective.

Perangkat pembelajaran yang dikembangkan dikatakan valid jika perangkat berdasarkan teori yang memadai (validasi isi) dan semua komponen perangkat pembelajaran satu samalain berhubungan secara konsisten (validitas konstruk). Indikator yang digunakan untuk menyatakan bahwa perangkat pembelajaran yang dikembangkan adalah valid sebagai berikut : (1) validitas isi, menunjukkan bahwa perangkat yang dikembangkan didasarkan pada kurikulum atau pada rasional teoritik yang kuat; (2) validasi konstruk, menunjukkan konsistensi internal antar komponen-komponen perangkat. Pada validasi konstruk ini, dilakukan serangkaian penelitian untuk memeriksa apakah komponen perangkat yang satu tidak bertentangan dengan komponen lainnya.

\section{Kemampuan Berpikir Kritis}

Ennis ( $1996: 1-2$ ) mendefinisikan berpikir kritis sebagai suatu proses berpikir dengan tujuan untuk membuat keputusan - keputusan yang dapat dipertanggungjawabkan mengenai apa yang akan diyakini dan apa yang akan dilakukan. Dalam memutuskan apa yang akan dipercaya dan apa yang akan dilakukan, diperlukan informasi yang reliabel dan pemahaman terhadap topik atau lapangan studi. Berdasarkan semua hal tersebut seseorang dapat mengambil keputusan yang reliabel. Keputusan mengenai keyakinan sangat penting, suatu kunci dalam memutuskan suatu keyakinan sering merupakan sebuah argumen. Berdasarkan definisi Ennis maka seseorang yang berpikir kritis mampu mengambil keputusan mengenai apa yang akan diyakini dan apa yang akan dilakukan berdasarkan informasi yang dapat dipercaya dan pemahaman terhadap topik yang dihadapi.

Kemampuan berpikir kritis adalah kemampuan berpikir siswa secara beralasan dan pertimbangan mendalam yang dapat membantu dalam membuat, mengevaluasi, mengambil, dan memperkuat suatu keputusan atau kesimpulan tentang situasi matematika yang dihadapinya.

Indikator - indikator berpikir kritis yang digunakan dalam penelitian ini sebagai berikut:

a) Mengindentifikasi

Indikator : memberikan argumen dengan benar dan memberikan alasan dengan benar.

b) Menggeneralisasi

Indikator : menemukan konsep dan menunjukkan bukti pendukung untuk generalisasi dengan benar.

c) Menganalisis

Indikator : dapat memilih informasi yang penting, tepat dalam memilih strategi yang benar dalam menyelesaikannya, serta memberi alasan atau melakukan perhitungan.

d) Mengklarifikasi

Indikator : memperbaiki kesalahan dalam pemecahan masalah dan memberi penjelasan dengan benar.

Self Efficacy

Self efficacy adalah suatu keyakinan seseorang terhadap kemampuan yang dimilikinya. Bandura (1994) mendefinisikan Self efficacy sebagai berikut:

"Self - efficacy is defined as people's beliefs about their capabilities to produce designated levels of performance that exercise influence over events that 
affects their lives. Self - efficacy beliefs determine how people feel, think, motivate themselves and behave."

Dengan demikian Self efficacy didefinisikan sebagai kepercayaan seseorang tentang kemampuannya untuk menghasilkan tingkat kinerja sehingga memberikan pengaruh pada kehidupannya. Self efficacy menentukan bagaimana perasaan, pikiran, motivasi diri, dan tingkah laku seseorang. Selain itu, Albert Bandura ( dalam Liu \& Koirala, 2009), "self- efficacy refers to learnes beliefs about their ability to accomplish certain tasks".

Self - efficacy memiliki peranan penting dalam keberhasilan siswa menyelesaikan permasalahan matematika. Bandura (1997), "Mathematics self efficacy is defined as an individual's beliefs or perceptions with respect to his or her abilities in mathematics". Artinya, self - efficacy matematis adalah kepercayaan diri dan pandangan seseorang terhadap kemampuan menyelesaikan berbagai bentuk tugas matematika, yaitu mulai dari memahami konsep untuk memecahkan masalah dalam matematika, sampai dengan Pengukuran self - efficacy juga memiliki empat karakteristik Hendriana (Yolanda,2015), yaitu (1) percaya pada kemampuan sendiri, yaitu suatu keyakinan diri sendiri atas kemampuannya dalam mengevaluasi serta mengatasi segala fenomena yang terjadi, (2) bertindak mandiri dalam mengambil keputusan, yaitu dapat bertindak dalam mengambil keputusan terhadap apa yang dilakukan secara mandiri tanpa banyak melibatkan orang lain, (3) memiliki konsep diri yang positif, yaitu adanya penilaian yang baik dari dalam diri sendiri, baik dari pandangan maupun tindakan yang dilakukan sehingga menimbulkan rasa positif terhadap diri sendiri, dan (4) berani mengungkapkan pendapat, yaitu mampu mengutarakan sesuatu dalam diri yang ingin diungkapkan kepada orang lain tanpa adanya paksaan atau hambatan untuk mengungkapkan perasaan tersebut.

Dalam penelitian ini Self Efficacy adalah keyakinan (beliefs) tentang kemampuan seseorang untuk mengorganisasi dan melaksanakan tindakan guna pencapaian tetentu mengambil kesimpulan.

\section{Model Problem Based Learning (PBL)}

Model Problem Based Learning (PBL) adalah model pembelajaran dengan pendekatan pembelajaran siswa pada masalah autentik sehingga siswa dapat menyusun pengetahuan sendiri, menumbuhkembangkan keterampilan, yang lebih tinggi, memandirikan siswa dan meningkatkan kepercayaan diri sendiri (M.Hosnan,2014:295). Model ini bercirikan penggunaan masalah dalam kehidupan nyata sebagai sesuatu yang harus dipelajari siswa untuk melatih dan meningkatkan keterampilan berpikir kritis dan pemecahan masalah untuk mendapatkan pengetahuan konsep - konsep penting, dimana tugas guru harus memfokuskan diri untuk membantu siswa mencapai keterampilan mengarahkan diri.Pembelajaran berbasis masalah penggunaannya di dalam tingkat berpikir yang lebih tinggi, dalam situasi berorientasi pada masalah, termasuk bagaimana belajar. Dengan demikian, model PBL merupakan salah satu model pembelajaran yang banyak melibatkan siswa dalam prosesnya. Siswa ditempatkan sebagai subjek belajar dan guru sebagai fasilitator.

Model pengembangan yang digunakan dalam penelitian adalah model Dick \& Carey.Model pengembangan Dick \& Carey digunakan karena menurut Trianto (2010) mengatakan bahwa Dick \& Carey menunjukkan bahwa telah banyak pengembangan bahan ajar yang mengikuti urutan secara ajeg dan berhasil mengembangkan bahan ajar yang efektif. Seperti penelitian yang dilakukan oleh Mustafa, Sinaga, dan Asmin (2017), bahwasanya telah diperoleh suatu perangkat pembelajaran berbasis masalah yang memenuhi kriteria valid, praktis, dan efektif dengan model pengembangan Dick \& Carey. Kemudian Suparman (2014) menyatakan model pengembangan pembelajaran The Systematic Design of Instructional karangan Dick and Carey memiliki setiap langkah yang terhubungkan dengan langkah-langkah merevisi kegiatan pembelajaran (umpan balik). Selanjutnya Dick \& Carey (dalam Uno, 2011) menyatakan secara umum gambaran desain pembelajaran Dick \& Carey sebagai berikut: (1) model Dick \& Carey terdiri dari 10 langkah dimana setiap langkah sangat jelas maksudnya dan tujuannya, sehingga sangat cocok bagi perancang pemula sebagai dasar untuk mempelajari model desain yang lain; (2) kesepuluh langkah pada model Dick \& Carey menunjukkan hubungan yang sangat jelas dan tidak terputus atas langkah yang satu dengan langkah yang lain, sistemnya sangat ringkas, namun isinya padat dan jelas; (3) langkah awal dari model Dick \& Carey sesuai dengan kurikulum perguruan tinggi maupun sekolah menengah dan sekolah dasar, yaitu mengidentifikasi tujuan pembelajaran.

\section{METODE PENELITIAN}

Jenis penelitian ini adalah penelitian pengembangan (Research and Development). Penelitian ini merupakan penelitian pengembangan yaitu pengembangan perangkat pembelajaran untuk menumbuh kembangkan kemampuan berpikir kritis dan self efficacy siswa. Penelitian ini menggunakan model pengembangan Dick and Carey. Perangkat pembelajaran yang dikembangkan adalah Buku Guru dan Buku Siswa.Penelitian ini dilaksanakan di SMA Sultan Iskandar Muda Medan yang akan di laksanakan pada semester ganjil tahun ajaran 2017/2018 di kelas XI dengan materi Program Linear. Instrumenpenelitian ini menggunakan tes kemampuan awal matematika, tes kemampuan berpikir kritis dan angketSelf efficacy ,Subjek dalam penelitian ini adalah siswa kelas XI SMA Swasta Sultan Iskandar Muda, yang masingmasing berjumlah 40 orang tiap kelas dan objek dalam 
Vol. 13, No. 2, Desember 2020

penelitian ini adalah perangkat pembelajaran matematika materi program linear berupa Buku Siswa (BS) dan Buku Guru (BG).

\section{Teknik Analisis Data}

Tujuan analisis data dalam penelitian ini digunakan untuk menjawab kevalidan dan keefektifan perangkat pembelajaran berdasarkan model pembelajaran Problem Based Learning yang dikembangkan merujuk pada rumusan masalah dan pertanyaan penelitian. Untuk melihat kevalidan perangkat pembelajaran berdasarkan rata - rata skor masing - masing perangkat pembelajaran yang telah divalidasi, kepraktisan, dan keefektifan pembelajaran dilihat dengan ketuntasan hasil belajar berpikir kritis matematis siswa secara klasikal, analisis aktivitas siswa, serta respon siswa selama mengikuti pembelajaran dengan menggunakan perangkat pembelajaran berdasarkan model Problem Based Learning yang dikembangkan

\section{HASIL PENELITIAN}

Setelah dilakukan pembelajaran untuk setiap kelas eksperimen maka data hasil posttest diperoleh sebagai berikut:

Tingkat Kemampuan Berpikir Kritis Matematis

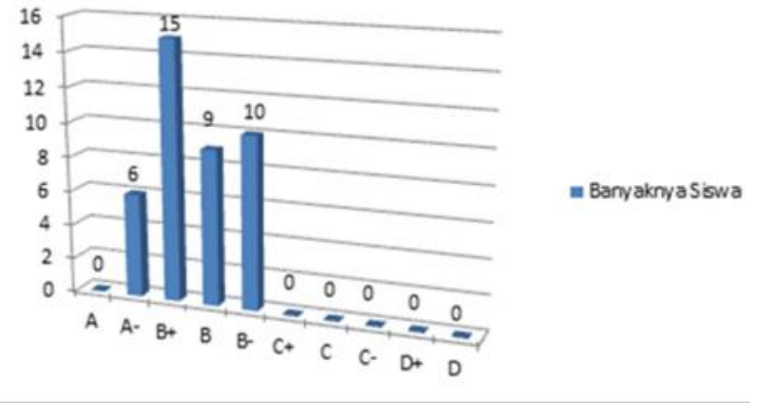

Gambar 1. Hasil postes uji coba I

Terlihat bahwa kriteria ketuntasan belajar siswa diperoleh bahwa banyaknya yang tuntas belajar yaitu 30 orang dari 40 orang siswa $(75 \%)$ dari jumlah siswa. Banyaknya siswa yang tidak tuntas adalah 10 orang dari 40 orang siswa (25\%) dari jumlah siswa. Selanjutnya secara klasikal bahwa suatu pembelajaran dipandang telah tuntas terdapat $85 \%$ siswa yang mengikuti tes telah mencapai skor minimal 2,67. Dengan demikian hasil postes pada ujicoba I belum memenuhi kriteria ketuntasan klasikal.

Tingkat Kemampuan Berpikir Kritis Matematis

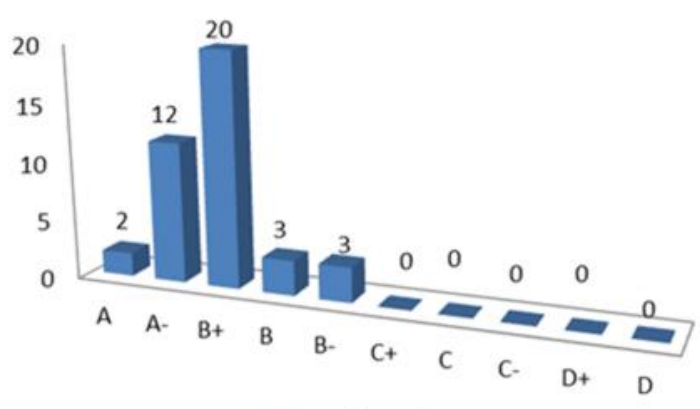

- Banyaknya Siswa

\section{Gambar 2. Hasil postes uji coba II}

Terlihat bahwa ketuntasan belajar siswa secara daya serap dari hasil kemampuan berpikir kritis matematis yaitu banyaknya siswa yang tidak tuntas adalah 3 orang dari 40 orang siswa $(7,5 \%)$, sesuai dengan criteria ketuntasan belajar siswa secara daya serap, yaitu minimal $85 \%$ siswa yang mengikuti pembelajaran mampu mencapai skor $\geq 2,67$. Dengan demikianhasil postes kemampuan berpikir kritis matematis pada uji coba 2 telah memenuhi kriteria pencapaian ketuntasan secara daya serap.

Tabel 1. Rata - rata ujicoba self Efficacy setiap indikator pada uji coba I.

\begin{tabular}{|l|l|c|c|}
\hline No & Aspek & $\begin{array}{c}\text { Rata-rata } \\
\text { Skor Per } \\
\text { Indikator }\end{array}$ & $\begin{array}{c}\text { Rata-rata } \\
\text { Skor Total }\end{array}$ \\
\hline 1 & $\begin{array}{l}\text { Pengalaman akan } \\
\text { kesuksesan }\end{array}$ & 3,10 & \multirow{2}{*}{3,17} \\
\hline 2 & $\begin{array}{l}\text { Pengalaman } \\
\text { individu lain }\end{array}$ & 3,22 & \multirow{2}{*}{} \\
\hline 3 & Pendekatan sosial & 3,09 & \multirow{2}{*}{} \\
\hline 4 & $\begin{array}{l}\text { Keadaan fisiologis } \\
\text { dan emosional }\end{array}$ & 3,25 & \\
\hline
\end{tabular}

Tabel 2. Rata - rata ujicoba Self efficacy setiap indikator pada Uji coba II.

\begin{tabular}{|l|l|c|c|}
\hline No & Aspek & $\begin{array}{c}\text { Rata-rata } \\
\text { Skor Per } \\
\text { Indikator }\end{array}$ & $\begin{array}{c}\text { Rata-rata } \\
\text { Skor Total }\end{array}$ \\
\hline 1 & $\begin{array}{l}\text { Pengalaman akan } \\
\text { kesuksesan }\end{array}$ & 3,19 & \multirow{2}{*}{3,25} \\
\hline 2 & $\begin{array}{l}\text { Pengalaman } \\
\text { individu lain }\end{array}$ & 3,34 & \multirow{2}{*}{} \\
\hline 3 & Pendekatan sosial & 3,18 & \\
\hline 4 & $\begin{array}{l}\text { Keadaan fisiologis } \\
\text { dan emosional }\end{array}$ & 3,30 & \\
\hline
\end{tabular}

Dapat dilihat bahwa skor rata-rata indikator paling tertinggi yaitu pengalaman akan individu lain, kemudia diikuti oleh indikator keadaan fisiologis dan emosional, pengalaman akan kesuksesan, dan yang terakhir yaitu indikator pendekatan sosial. Dengan demikian dapat disimpulkan bahwa self-efficacy siswa pada uji coba 2 dominan melihat dari segi pengalaman akan individu lain.

Persentase Keterlaksanaan Perangkat Pembelajaran pada Tiap-tiap Pertemuan

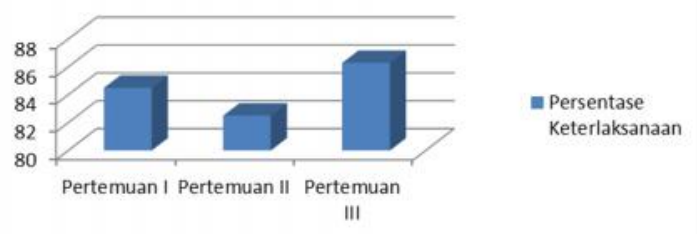

Pengembangan Perangkat Pembelajaran Matematika Untuk Meningkatkan Kemampuan Berpikir Kritis Dan Self Efficacy Siswa Dengan 


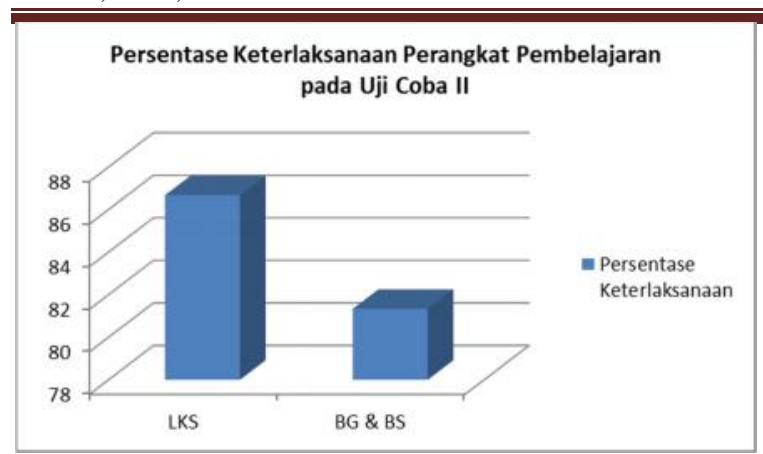

Gambar 3. Hasil uji coba II

Terlihat bahwa persentase rata-rata pada ketiga pertemuan memenuhi kriteria keterlaksanaan perangkat pembelajaran dengan kategori baik.Kemudian persentase rata-rata keterlaksanaan tiap-tiap perangkat pembelajaran $\mathrm{BG}$ dan $\mathrm{BS}$ juga memenuhi kriteria terlaksana dengan kategori baik. Hal ini tentu berdampak pada keterlaksanaan perangkat pembelajaran secara keseluruhan untuk tiga kali.

\section{PEMBAHASAN}

Berdasarkan hasil analisis data terhadap rata-rata posttest kedua kelas, kelas yang diajar melalui model pembelajaran problem based learning diperoleh peningkatan. Hal ini menunjukkan bahwa perangkat pembelajaran tersebut dapat dipergunakan.

Hasil penelitian ini dapat menjadi referensi dikarenakan dengan pengembangan perangkat buku guru dan buku siswa dapat meningkatkan hasil post test siswa dibandingkan

Model pembelajaran kontekstual dengan komponen-komponennya adalah model pembelajaran yang didukung oleh banyak teori belajar. Teori kontsruktivisme, yakni menekankan pentingnya siswa membangun atau mengkontsruk pengetahuannya sendiri, teori belajar Dewey tentang pentingnya bertanya dan refleksi dalam pembelajaran. Teori belajar Piaget tentang sangat penting adanya penilaian yang autentik dan belajar dengan menemukan sendiri pengetahuan siswa pada saat proses pembelajaran, teori belajar Ausubel yang menekankan betapa pentingnya belajar yang bermakna, teori belajar Bruner yang juga mengemukakan tentang pentingnya belajar penemuan, teori belajar Vygotsky, Piaget dan Bruner tentang pentingnya belajar secara berkelompok.

Berdasarkan hasil analisis data terhadap rata-rata skor kemudian dihitung untuk perbedaan kedua kelas, kelas yang diajar melalui model pembelajaran problem based memperoleh rerata skor self efficacy

Dari hasil analisis yang dilakukan terhadap

\section{KESIMPULAN}

Berdasarkan hasil analisis data dan hasil penelitian, kesimpulan yang merupakan jawaban atas pertanyaan penelitian yang diajukan adalah:

1. Keefektivan perangkat pembelajaran dengan model Problem Based Learning untuk meningkatkan kemampuan berpikir kritis dan self efficacy siswa sudah efektif untuk digunakan dalam pembelajaran, berdasarkan hasil validasi, kepraktisan perangkat dan efektivitas perangkat pembelajaran, dan respon siswa.

2. Peningkatan kemampuan berpikir kritis siswa dengan menggunakan perangkat pembelajaran model Problem based learning pada materi program linear adalah rata - rata pencapaian kemampuan berpikir kritis siswa pada ujicoba I sebesar 79,89 meningkatkan menjadi 88,65 pada uji coba II. Hal ini menunjukkan kemampuan berpikir kritis siswa menggunakan perangkat pembelajaran yang dikembangkan dengan model Problem based learning mengalami peningkatan dari uji coba I ke uji coba II. Peningkatan terbesar yaitu 0,26 pada indikator mengindentifikasi, sementara peningkatan terkecil pada indikator menganalisis hanya sebesar 0,08 .

3. Terdapat peningkatan self efficacy siswa dengan menggunakan pengembangan perangkat pembelajaran dengan model problem based learning. Pada ujicoba I diperoleh peningkatan self efficacy siswa sebesar $g=0,68$ atau berada pada kategori sedang. Sedangkan pada uji coba II diperoleh peningkatan self efficacy siswa sebesar $g=0,71$ atau berada pada kategori tinggi.

\section{UCAPAN TERIMAKASIH}

Pada kesempatan ini penulis ingin mengucapkan terima kasih yang tulus dan penghargaan yang setinggitingginya kepada semua pihak yang telah membantu penulis dalam menyelesaikan tesis ini dalam waktu yang tepat. Semoga Tuhan yang Maha Kuasa membalas dengan kebaikan yang setimpal. Terima kasih dan penghargaan penulis sampaikan kepada kepada yang teristimewa :

1. Ibu Yulita Molliq, M.Sc, Ph.D, selaku dosen pembimbing I dan Bapak Dr. Kms. M. Amin Fauzi, M.Pd selaku dosen pemimbing II, yang telah meluangkan waktu disela-sela kesibukannya untuk memberikan bimbingan, arahan dan saransaran yang sangat berarti bagi penulis dalam penyusunan tesis ini sampai selesai.

2. Bapak Prof. Dr. Edi Syahputra, M.Pd dan Bapak Dr. Mulyono, M.Si selaku ketua dan sekretaris Program Studi Pendidikan Matematika Pascasarjana UNIMED.

3. Bapak Prof. Dr. Edi Syahputra, M.Pd, Bapak Prof. Dr. Mukhtar, M.Pd, Dr. Edy Surya , M.Si,selaku narasumber yang telah banyak memberikan masukan pemikiran serta gagasan pada penulis sehingga menambah wawasan pengetahuan penulis dalam penyempurnaan penulisan tesis ini.

4. Bapak Hendri Dalimunte,M.A selaku staf Prodi Pendidikan Matematika

5. Bapak Prof. Dr. Bornok Sinaga, M.Pd selaku Direktur Program Pascasarjana UNIMED yang telah memberikan kesempatan serta bantuan administrasi selama pendidikan di Universitas Negeri Medan. 
Vol. 13, No. 2, Desember 2020

6. Seluruh Bapak dan Ibu Dosen Pendidikan Matematika Program Pascasarjana UNIMED yang telah banyak memberikan ilmu pengetahuan yang sangat berharga bagi pengembangan wawasan keilmuan penulis selama mengikuti studi dan penulisan tesis.

7. Kepala SMA Sultan Iskandar Muda serta Dewan Gurudan staf administrasi yang telah memberikan izin dan kesempatan kepada penulis untuk melakukan penelitian di sekolah tersebut.

8. Secara khusus dan teristimewa penulis mengucapkan terima kasih dan hormat yang setinggi-tingginya kepada orangtua saya AyahYan Rosa Lubis dan Ibu Dameria Gultom, Suami saya Maruli Situmorang, dan kedua anak saya Ester Ellora Danan Situmorang dan Yosua Prima Maruli Situmorang berkat izin dan semua kasih sayang, doa, motivasi, jerih payah serta dukungan penuh untuk setiap langkah dalam menyelesaikan perkuliahan dan penulisan tesis ini.

9. Rekan-rekan mahasiswa seperjuangan Program Studi Pendidikan Matematika Program Pascasarjana Universitas Negeri Medan khususnya kelas B-3 angkatan XXIII tahun 2013.

\section{REFERENSI}

[1] Bandura, A. (1994). Perceived Self - Efficacy in Cognitiv Development and Functioning. Educational Psychologist, 28, 117-148.

[2]Bandura, A. (1997). Self - Efficacy, The exercise of control, New York. W. H Freeman.

[3] Campbell, C.P (1999). Instructional Materials, Their Preparation and Evaluation, Journal Of European Industrial Training, Vol.23, No 2.

[4] Ennis. (1996), Critical Thinking.University Of Illinois.

[5]Harida. (2012). Self - Efficacy dan Prestasi Belajar Siswa Dalam Pembelajaran IPA - KIMIA, Jurnal Pendidikan Matematika dan IPA Vol3, No1, Januari 2013.

[6]Hosnan,M.(2014). Pendekatan Saintifik dan Kontekstual dalam Pembelajaran Abad 21.Bogor : Ghalia Indonesia.

[7] Mustafa; Sinaga $\quad$ B., \& Asmin. (2017). Development of Learning Devices Through Problem Based Learning Model to Improve Student Metacognition Skill at SMPN 17 Medan. Journal Of Education and Practice. Vol.8, No.24.

[8] Nieveen,N. (2007). Prototyping to Reach Product Quality. PloompT;Nieeven,N; Gustafson, $\mathrm{K}$;Branch, R.M; dan Van den Akker, J (eds). Design Approaches and Tools in Education and Training. London : Kluwer Academic Publisher.

[9] Nurhadi,(2004).Pembelajaran Kontekstual dan Penerapannya dalam KBK. Malang, UM Press

[10]Nurina Happy. (2014). Keefektifan PBL ditinjau dari Kemampuan Berpikir Kritis dan Kreatif Matematis serta Self - esteem Siswa SMP, Jurnal Riset Pendidikan Matematika, Volume 1, No 1, Mei 2014.
[11]Simbolon, M., Mulyono., Syahputra. E., and Surya. E., (2017). The Efforts to Improving the Mathematical Critical Thingking Student's Ability through Prpblem solving Learning Strategy by using Macro Media Flash. American Journal Of Educational research, Vol.5, No.7, 2017.

[12]Syahputra.E., and Surya. E, (2017)., The Development of Learning Model Based Learning to Construct High- Order Thingking Skill on the Learning Mathematics of $11^{\text {th }}$ Grade In SMA/MA Journal Of Education and Practice, ISSN 22221735 Vol.8, No.6, 2107.

[13]Suparman, A. (2014. Desain Instruksional Modren. Jakarta : Erlangga.

[14]Trianto, (2011). Model Pembelajaran Terpadu Konsep, Strategi Dan Implementasinya Dalam Kurikulum Tingkat Satuan Pendidikan (KTSP). Jakarta : Bumi Aksara.

[15]Uno, H.B. (2011). Model Pembelajaran : Menciptakan Proses Belajar Mengajar yang Kreatif dan Efektif. Jakarta : Bumi Aksara. 